\title{
Pathogens associated with grain discolouration and their management in paddy (Oryza sativa L.)
}

\author{
K.B. Yadahalli* and Jyoti A. Konnur \\ Department of Plant Pathology, College of Agriculture \\ (University of Agricultural Sciences, Dharwad), Hanumanamatti (Karnataka) India \\ (Emil : kbyadahalli@gmail.com)
}

\begin{abstract}
Grain discoloration complex disease of rice is an emerging threat to rice crop all over the world and it acquires particular importance as it results in qualitative loss of harvested crop. So the present study was carried out to identify different fungi associated with disease and their management. The discoloured seed samples were collected from different farmer's field during survey. Totally seven fungi including both saprophytic as well as pathogenic were isolated and identified from both blotter and potato dextrose agar method viz., Curvularia lunata (36.30\%), Helminthosporium oryzae (25.6 \%), Fusarium moniliformae (19.6 $\%)$, Colletotrichum gloeosporioids (8.1\%) and Alternaria spp. (7.01\%) were predominantly associated with discoloured paddy seeds. Other saprophytic fungi like Aspergillus spp. (16.6 \%) and Rhizopus spp. (12.1\%) were frequently observed. Similarly among the eleven treatment including control, seed treatment with carbendazim $50 \mathrm{WP}\left(2 \mathrm{~g} \mathrm{~kg}^{-1}\right)$ with two sprays of tebuconazole $250 \mathrm{EC}$ at 0.1 per cent concentration and tricyclazole $18 \%+$ mancozeb $62 \% \mathrm{WP}$ at 0.2 per cent first spray during flowering stage and second spray during 15 days after first spray reducing discoloured panicle by 61.46 per cent and 59.92 per cent, respectively.
\end{abstract}

Key Words : Paddy, Pathogens, Chemical control, Discoloration, Qualitative, Treatment

View Point Article : Yadahalli, K.B. and Konnur, Jyoti A. (2021). Pathogens associated with grain discolouration and their management in paddy (Oryza sativa L.). Internat. J. agric. Sci., 17 (2) : 250-255, DOI:10.15740/HAS/IJAS/17.2/250-255. Copyright@2021: Hind AgriHorticultural Society.

Article History : Received : 22.02.2021; Revised : 25.02.2021; Accepted : 14.03.2021

\footnotetext{
* Author for correspondence :
} 